\title{
Efektivitas Pelatihan Kesadaran Diri untuk Meningkatkan Kedisiplinan Siswa
}

\author{
Amy Novalia Esmiati', Nanik Prihartanti ${ }^{2}$, Partini ${ }^{3}$ \\ ${ }^{1,2,3}$ Fakultas Psikologi, Universitas Muhammadiyah Surakarta, Indonesia
}

\begin{tabular}{l}
\hline Info Artikel \\
\hline Sejarah Artikel: \\
Diterima \\
2I Januari 2020 \\
Direview \\
08 Februari 2020 \\
Disetujui \\
24 Februari 2020 \\
Dipublikasikan \\
27 Februari 2020 \\
\hline Keywords: \\
Kedisiplina; \\
Pelatihan \\
Kesadaran Diri
\end{tabular}

\begin{abstract}
Abstrak
Abstrak. Kedisiplinan memiliki peranan penting dalam membentuk pribadi yang taat pada aturan-aturan yang ada dan bertanggung jawab terhadap tugas yang harus dikerjakan. Kedisiplinan dapat meningkat, salah satunya dipengaruhi oleh kesadaran diri. Sehingga perlu adanya pengelolaan kesadaran pada diri untuk memahami, mengenali, mengakui, dan mengekspresikan diri secara akurat. Penelitian ini bertujuan untuk menguji efektivitas pelatihan kesadaran diri dalam meningkatkan kedisiplinan pada siswa. Metode penelitian yang digunakan dalam penelitian ini adalah metode Quasi Experimental Design dengan teknik pengambilan sampel purposive sampling, dan dengan model desain eksperimen pre test-post test control group design. Subjek dalam penelitian ini yaitu siswa SMK yang memiliki kategori tingkat kedisiplinan yang rendah. Keseluruhan subjek dalam penelitian ini berjumlah 20 siswa, yang terbagi dalam 2 kelompok yaitu kelompok eksperimen dan kelompok kontrol. Uji hipotesis dalam penelitian ini menggunakan teknik Man Whitney U-Test dengan nilai $z=-3.485$ dan sig ( 2 tailed $)=0,000$ dimana $(p<0,0 \mathrm{l})$, yang berarti terdapat perbedaan tingkat kedisiplinan yang signifikan antara kelompok yang diberikan pelatihan kesadaran diri dibandingkan dengan kelompok yang tidak diberikan pelatihan kesadaran diri.
\end{abstract}

\section{The Effectiveness of Self Awareness Training to Improve Student Discipline}

Abstract. Discipline has an important role in managing individuals who obey the rules that exist and are responsible for the tasks that must be done. Discipline can increase, one of which is developed by self-awareness. Because it needs to be considered, awareness must be approved, approved, recognized, and approved. The purpose of this study is to analyze effectiveness of self-awareness training to improve students discipline. The research method used in this study were the Quasi Experimental Design method with a purposive sampling technique and the pre-test design model of the control group design. The subjects in this study were vocational students who had a low level of discipline category. All subjects in this study were 20 student experiments, which were divided into 2 groups: the experimental group and the control group. Hypothesis testing in this study use the Man Whitney U-Test technique with a value of $z=-3,485$ and sig (2 tailed) = 0,000 where $(p<0.01)$, which on average contains a significant level of discipline compared to the group that is not given self-awareness training.

*Alamat korespondensi:

[J. A. Yani, Mendungan, Pabelan, Kec. Kartasura, Kabupaten Sukoharjo, Jawa Tengah 57I62]

[amynovalial8@gmail.com] 


\section{Pendahuluan}

Pendidikan adalah suatu usaha sadar dan terencana untuk mewujudkan suasana belajar dan proses pembelajaran agar peserta didik secara aktif mengembangkan potensi diri. Salah satu tempat untuk menempuh pendidikan yaitu sekolah. Sekolah mempunyai peranan penting dan tanggung jawab penting dalam membantu siswa mencapai tugas perkembangannya (Yusuf, 200I). Peraturan yang dibuat merupakan kebijakan sekolah yang tertulis dan berlaku sebagai standar untuk tingkah laku siswa sehingga siswa mengetahui batasan-batasan dalam bertingkah laku. Siswa yang disiplin adalah siswa yang taat terhadap peraturan dan tata tertib sekolah, taat terhadap kegiatan belajar dan tugas di sekolah, taat terhadap norma-norma yang berlaku, dan bertanggung jawab terhadap apa yang diucapkan dan dilakukan. Dengan pemberlakuan disiplin, siswa belajar beradaptasi dengan lingkungan yang baik, sehingga muncul keseimbangan diri dalam hubungan dengan orang lain (Tu'u, 2004).

Pada saat ini kedisiplinan sekolah sudah mulai tidak dihiraukan oleh peserta didik sehingga beberapa pihak sekolah mulai menerapkan peraturan yang lebih ketat agar peserta didik merasa lebih jera. Hasil penelitian yang dilakukan Simba dkk (2016) menjelaskan bahwa berperilaku tidak disiplin membuat siswa kehilangan fokus pada tujuan pendidikan yang dicapai melalui kerja keras, manajemen waktu, rasa hormat terhadap orang lain dan penentuan nasib sendiri. Kemudian Arvianola, dkk (2016) juga mengungkapkan bahwa terdapat permasalahan yang terjadi pada dunia pendidikan saat ini mengenai krisis etika dan krisis moral anak di sekolah, sehingga semakin lama akan semakin mempengaruhi kualitas keberhasilan pendidikan di suatu sekolah. Etika yang di maksud yaitu ketertiban, kedisiplinan, sopan santun, dan sikap hormat siswa ketika berada di sekolah maupun berada di masyarakat juga mengalami penurunan.

Kurangnya kedisiplinan pada siswa ini juga terjadi di salah satu SMK di Kartasura. Tercatat dari hasil penyebaran angket terhadap 80 siswa diketahui terdapat pelanggaran kedisiplinan diantaranya yaitu tidak masuk sekolah dengan sengaja (membolos) $75 \%$, terlambat masuk sekolah/masuk kelas $80 \%$, terlambat datang upacara/tidak mengikuti upacara $25 \%$, keluar jam pelajaran tanpa izin $40 \%$, meninggalkan sekolah tanpa izin $45 \%$, tidak mengerjakan tugas yang diberikan guru $40 \%$, tidak memakai atribut sekolah lengkap (dasi, ikat pinggang, bet nama, hasduk pramuka) $60 \%$, rambut tidak rapi (panjang pada anak laki-laki) 60\%, sepatu tidak sesuai standar $50 \%$, seragam dikeluarkan 75\%. Pelanggaran kedisiplinan (perlakuan siswa) yaitu merokok dilingkungan sekolah $40 \%$, mengeluarkan kata-kata tidak baik/kotor di lingkungan sekolah $45 \%$, berkelahi dengan teman di sekolah $30 \%$. Dari beberapa macam perilaku bermasalah yang dilakukan siswa, dapat disimpulkan bahwa siswa di SMK tersebut mengalami permasalahan yaitu kedisiplinan yang rendah.

Data angket tersebut diperkuat dari hasil observasi dan wawancara guru BK, yang diketahui bahwa perilaku pelanggaran siswa di sekolah baik kedisiplinan dari tata tertib maupun disiplin belajar diketahui cukup rendah. Siswa sering membolos, terlambat, tidur di kelas, atribut seragam tidak lengkap, atribut tidak sesuai standar, mengeluarkan baju seragam sekolah, tidak memakai sepatu sesuai standar, kemudian keluar pada saat jam kelas lalu ke kantin, ketika bel masuk berbunyi siswa masih berada di kantin, pada waktu solat siswa tidur, siswa juga merokok di lingkungan sekolah, dan tidak mengerjakan tugas yang diberikan guru.

Tu'u (2004) menjelaskan bahwa disiplin merupakan upaya mengikuti dan mentaati peraturan, nilai, dan hukum yang berlaku, serta pengikutan dan ketaatan tersebut terutama muncl karena adanya kesadaran diri bahwa hal itu berguna bagi kebaikan dan keberhasilan dirinya. Tu'u (2004) juga menjelaskan terdapat faktor penyebab munculnya sikap disiplin yaitu diantaranya adanya kesadaran diri, taat terhadap peraturan yang mengatur perilaku individu, adanya alat pendidikan untuk membentuk perilaku yang sesuai dengan nilai-nilai yang ditentukan atau diajarkan, dan hukuman sebagai upaya penyadaran. Jinot (20I8) faktor penyebab kurangnya disiplin dapat dipengaruhi oleh keluarga (gaya pengasuhan, orangtua yang bekerja, disiplin orangtua yang tidak efektif dan keluarga yang disfungsional), sikap siswa terhadap pendidikan dan sekolah, para pendidik, pengaruh kelompok sebaya dalam lingkungan sekolah. 
Terdapat upaya-upaya penanganan di sekolah terhadap timbulnya masalah-masalah yang dihadapi oleh remaja. Sekolah memberikan pendidikan formal dimana kegiatan belajar anak diatur sedemikian rupa. Waktu yang relatif singkat menentukan pembinaan perilaku dan kecerdasan anak didik. Apabila proses belajar mengajar tidak berjalan dengan baik, akan perilaku yang tidak wajar pada anak didik (Willis, 20l4). Baumann (2016) bahkan di sekolah yang relatif teratur, para guru harus berurusan dengan gangguan kecil sehari-hari seperti siswa berbicara atau bergerak selama pelajaran. Gangguan seperti itu disebabkan oleh kurangnya disiplin, hal tersebut dikaitkan dengan kinerja akademik yang lebih rendah. Untuk menghindari gangguan seperti itu siswa perlu meningkatkan kesadaran diri dan memiliki aturan kelas yang jelas secara konsisten.

Permasalahan yang terjadi tersebut dikarenakan adanya berbagai faktor yaitu kurangnya kesadaran diri siswa akan pentingnya berperilaku disiplin sehingga siswa kurang dapat mengontrol perilakunya. Hal itu didukung dengan kondisi lingkungan sekolah, dimana siswa mudah terpengaruh dengan ajakan teman untuk berperilaku tidak disiplin. Kedisiplinan yang rendah tersebut dapat ditingkatkan dengan adanya kesadaran diri (self-awareness). Abdurohman (2004) menjelaskan bahwa kesadaran diri ialah sesuatu hal yang penting untuk menunjukkan kejelasan dan pemahaman tentang perilaku seseorang.

Hasil penelitian yang dilakukan oleh Muchtar (2015) menjelaskan bahwa melalui layanan bimbingan kelompok sangat efektif dalam upaya meningkatkan kehadiran siswa, kemudian tingkat disiplin siswa pada awal pelajaran/ masuk kelas, selama proses pembelajaran dan mengakhiri pembelajaran (pulang sesuai jadwal). Flurentin (20I2) mengungkapkan bahwa latihan kesadaran diri mampu menumbuhkan karakter sesorang. Hatami (2016) menjelaskan bahwa pelatihan self-awareness (kesadaran diri) secara langsung meningkatkan kesadaran diri dan keyakinan diri dalam meningkatkan perilaku bermasalah. Nursetya (2014) juga melakukan penelitian untuk meningkatkan perilaku disiplin dengan menggunakan konseling dan reinforcrement positif.

Berdasarkan pemaparan beberapa pendapat di atas menunjukkan bahwa upaya untuk meningkatkan kedisiplinan ialah memberikan pelatihan kesadaran diri (self-awareness), dengan adanya kesadaran diri siswa mampu belajar dari pengalaman. Menurut Kolb (1996) suatu metode proses belajar mengajar yang mengaktifkan pembelajar untuk membangun pengetahuan dan keterampilan serta nilai-nilai juga sikap melalui pengalamannya secara langsung. Abdurohman (2004) juga menjelaskan bahwa sikap disiplin peserta didik juga berhubungan dengan kesadaran diri dalam diri peserta didik, peserta didik dinilai baik dalam belajar apabila mereka melaksanakan secara sadar dan terus menerus hal-hal yang telah ditetapkan atau telah di programkan oleh sekolah. Hasil penelitian dari Sutton (2016), Rasheed (2015), dan Soolgi \& Sungjae (2016) menunjukkan bahwa pentingnya kesadaran diri untuk mengetahui tentang diri sebagai pribadi dan fondasi serta hal-hal penting dalam kehidupan yang memengaruhi individu dalam berbagai cara, yang mampu meminimalkan kelemahan pribadi dalam pengembangan interaksi di banyak bidang dalam memasukkan dampak besar pada fungsi sehari-hari. Ini memiliki efek penting pada kinerja, dengan refleksi dan perhatian mendorong kegigihan dengan tugas-tugas. Maka dari itu perlu diupayakan pemberian intervesi yang tepat dan sesuai untuk meningkatkan kedisiplinan siswa. Berdasarkan deskripsi dari berbagai intervensi untuk meningkatkan kedisiplinan siswa maka muncul sebuah rumusan masalah. Rumusan masalah tersebut adalah "Bagaimana efektifitas pelatihan kesadaran diri (self awarness) untuk peningkatan kedisiplinan siswa?"

Penelitian ini juga dilakukan dengan tujuan untuk mengetahui efektivitas pelatihan kesadaran diri untuk meningkatkan kedisiplinan siswa. Kemudian peneliti juga memiliki hipotesa bahwa penerapan pelatihan kesadaran diri mampu meningkatkan kedisiplinan siswa.

\section{Metode}

Metode penelitian yang digunakan dalam penelitian ini adalah dengan menggunakan pendekatan kuantitatif eksperimental. Pemilihan subjek dalam penelitian ini melalui sampel purposive yakni suatu pemilihan kelompok subjek yang berdasar atas ciri atau sifat tertentu yang memiliki 
karakteristik seperti yang diinginkan (Hadi, 20I5). Subjek dalam penelitian ini yaitu siswa SMK yang memiliki kategori tingkat kedisiplinan yang rendah. Subjek berjumlah 20 orang yang memiliki kedisiplinan rendah atau sedang (berdasarkan hasil screening dengan skala kedisiplinan). Skala Kedisiplinan yang digunakan berdasarkan aspek-aspek dari Ahmadi (2007) yang berisi a) ketertiban terhadap peraturan, dan b) tanggung jawab. Keseluruhan dari subjek tersebut kemudian dibagi dalam dua kelompok secara random yaitu kelompok eksperimen dan kelompok kontrol.

Rancangan eksperimen dalam penelitian ini menggunakan Quasi eksperimental Design (eksperimen semu), dengan desain eksperimen model pre test-post test control group design yang merupakan bentuk desain klasik dengan prosedur randomisasi di tiap kelompok baik kelompok kontrol maupun kelompok eksperimen. Masing- masing kelompok kontrol maupun eksperimen sama-sama diberikan pre test dan post test, namun yang diberikan perlakuan hanya kelompok eksperimen (Creswell, 20I0).

Tabel I.

Desain Eksperimen

\begin{tabular}{cccccc}
\hline \multirow{2}{*}{ Kelompok } & Pre-test & Perlakuan & Post-test & Follow up \\
& $\mathrm{KE}$ & $\mathrm{Y}_{1}$ & $\mathrm{X}$ & $\mathrm{Y}_{2}$ & $\mathrm{Y}_{3}$ \\
& $\mathrm{KK}$ & $\mathrm{Y}_{1}$ & - & $\mathrm{Y}_{2}$ & $\mathrm{Y}_{3}$ \\
\hline
\end{tabular}

Keterangan:

R: randomisasi

$Y_{1}$ : pre test

KE:kelompok eksperimen $\quad Y_{2}$ : post test

KK·kelompok kontrol $\quad Y_{3}$ : follow up

$\mathrm{X}$ : perlakuan

Tabel 2.

Rancangan Intervensi

\begin{tabular}{|c|c|c|c|}
\hline Hari & Sesi & Tahapan Intervensi & Metode yang digunakan \\
\hline \multirow[t]{8}{*}{ I } & \multirow{3}{*}{$\begin{array}{l}\text { Sesi I } \\
\text { Pembukaan }\end{array}$} & Tahap I & Game (perkenalan) \\
\hline & & Tahap 2 & Menampilkan kontrak pelatihan \\
\hline & & Tahap 3 & $\begin{array}{l}\text { Penjelasan singkat materi } \\
\text { mengenai faktor kedisiplinan dan } \\
\text { pengetahuan mengenai kesadaran } \\
\text { diri }\end{array}$ \\
\hline & \multirow{2}{*}{$\begin{array}{l}\text { Sesi II } \\
\text { Memahami Diri }\end{array}$} & Tahap I & Mengisi whorksheet \\
\hline & & Tahap 2 & $\begin{array}{l}\text { Diskusi dampak negatif dari } \\
\text { perilaku disiplin }\end{array}$ \\
\hline & \multirow{2}{*}{$\begin{array}{l}\text { Sesi III } \\
\text { Mengenali emosi }\end{array}$} & Tahap I & Mengisi whorksheet dan konferensi \\
\hline & & Tahap 2 & Simulasi dan games emotions \\
\hline & Sesi Penutupan & Tahap I & Kesan dan pesan \\
\hline \multirow[t]{9}{*}{ II } & \multirow[t]{2}{*}{ Pembukaan } & Tahap I & Ice breaking \\
\hline & & Tahap 2 & Membahas tugas rumah \\
\hline & \multirow{2}{*}{$\begin{array}{l}\text { Sesi IV } \\
\text { Pengakuan diri yang } \\
\text { akurat }\end{array}$} & Tahap I & Mengenali diri \\
\hline & & Tahap 2 & Bertanya pada diri sendiri \\
\hline & $\begin{array}{l}\text { Sesi } \bigvee \\
\text { Analisis diri }\end{array}$ & Tahap I & Refleksi diri (pikiran dan perasaan) \\
\hline & \multirow[t]{2}{*}{$\begin{array}{l}\text { Sesi VI } \\
\text { Kepercayaan diri }\end{array}$} & Tahap I & $\begin{array}{l}\text { Memunculkan kesadaran diri yang } \\
\text { kreatif }\end{array}$ \\
\hline & & Tahap 2 & Mengekspresikan diri \\
\hline & \multirow{2}{*}{$\begin{array}{l}\text { Sesi VII } \\
\text { Penutupan }\end{array}$} & Tahap I & Kristalisasi \\
\hline & & Tahap 2 & Pemberian kesan dan pesan \\
\hline
\end{tabular}


Penelitian ini menggunakan metode analisis non parametrik dengan uji Mann Whitney $U$ Test dan Wilcoxon. Uji Mann Whitney $U$ Test bertujuan untuk melihat ada atau tidaknya pengaruh pelatihan kesadaran diri terhadap kedisiplinan pada kelompok eksperimen dan kelompok kontrol. Uji statistik Wilcoxon untuk membandingkan ada atau tidaknya perbedaan dua data yang saling berpasangan (pre-test dan post-test) pada kelompok eksperimen, dimana uji Wilcoxon untuk mengetahui peningkatan kedisiplinan siswa dengan mencari perbedaan skor pre-test dan post-test. Perhitungan secara lengkap menggunakan bantuan SPSS for Windows versi 16.0.

\section{Hasil}

Penelitian ini memiliki tujuan menguji efektivitas pelatihan kesadaran diri untuk meningkatkan kedisiplinan siswa di salah satu SMK di Kartasura. Dari hasil penelitian didapatkan bahwa pelatihan kesadaran diri dapat meningkatkan kedisiplinan siswa, ditunjukkan dengan adanya peningkatakan skor kedisiplinan sebelum diberikan dan setelah diberikan pelatihan kesadaran diri.

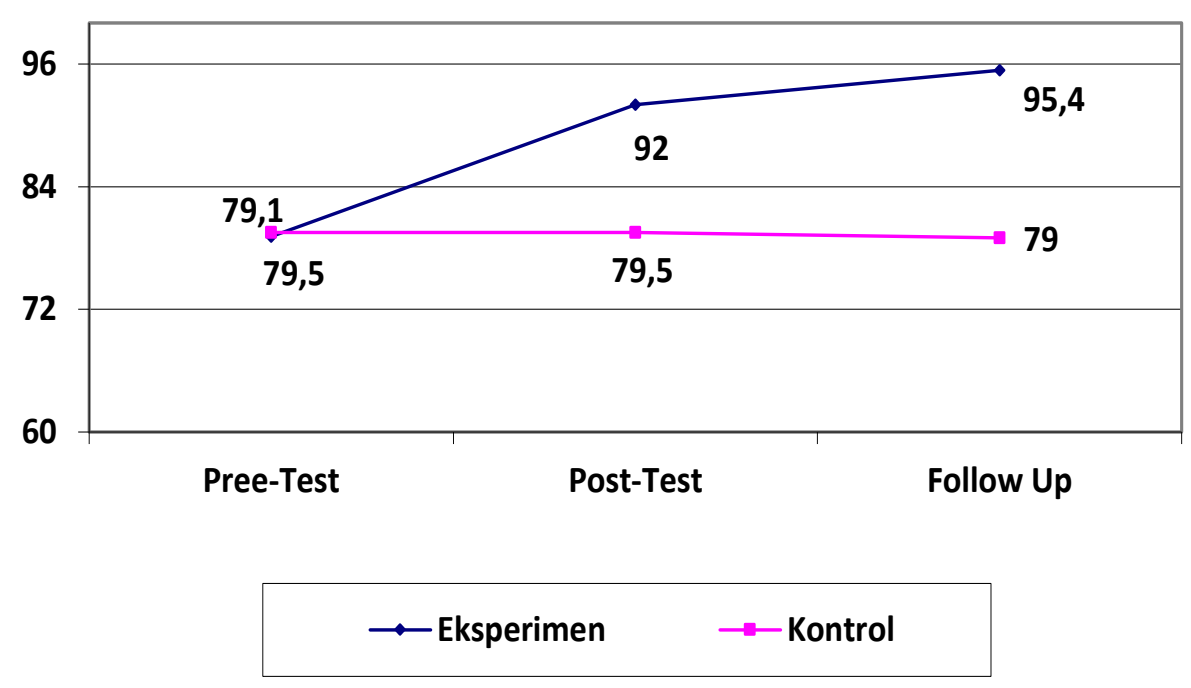

\section{Gambar I. Rata-Rata Skor Kelompok Eksperimen dan Kelompok Kontrol}

Berdasarkan tabel 3, dapat dijelaskan bahwa pada kelompok eksperimen, skor rata-rata sebelum diberikan pelatihan sebesar $79, \mathrm{I}$, setelah pemberian pelatihan kesadaran diri meningkat menjadi sebesar 92, ketika follow up skor menjadi 95,4 yang artinya terjadi pembelajaran yang berkelanjutan meskipun tidak diberikan pelatihan secara terus menerus dan masuk dalam kategori tinggi. Seluruh peserta mengalami kenaikan skor saat pretest-follow up, kecuali satu peserta mengalami penurunan skor pada saat follow up. Hasil dari kelompok control mendapat skor rata-rata pretest sebesar 79,5, kemudian tidak terjadi perubahan pada skor posttest, dan mengalami penurunan skor pada follow up yaitu 79. Hal ini diartikan bahwa kelompok kontrol tanpa diberikan perlakuan tetap dalam perilaku disiplin dengan kategori rendah dan sedang. Ini juga ditampilkan pada gambar I yang menunjukkan perubahan skor rata-rata pretest, postest, dan follow up dari kelompok kontrol dan kelompok eksperimen. 
Tabel 3.

Perubahan Skor Kedisiplinan Subjek Penelitian

\begin{tabular}{|c|c|c|c|c|c|c|c|}
\hline Kelompok & Subjek & $\begin{array}{c}\text { Skor } \\
\text { Pretest }\end{array}$ & $\begin{array}{c}\text { Kategori } \\
\text { Skor }\end{array}$ & $\begin{array}{c}\text { Skor } \\
\text { Posttest }\end{array}$ & $\begin{array}{c}\text { Kategori } \\
\text { Skor }\end{array}$ & $\begin{array}{c}\text { Skor } \\
\text { Follow up }\end{array}$ & $\begin{array}{l}\text { Kategori } \\
\text { Skor }\end{array}$ \\
\hline \multirow[t]{11}{*}{ Eksperimen } & BB & 85 & Sedang & 90 & Tinggi & 95 & Tinggi \\
\hline & SN & 69 & Rendah & 91 & Tinggi & 100 & Tinggi \\
\hline & SMS & 85 & Sedang & 90 & Tinggi & 94 & Tinggi \\
\hline & RMA & 87 & Sedang & 91 & Tinggi & 91 & Tinggi \\
\hline & SDS & 65 & Rendah & 94 & Tinggi & 93 & Tinggi \\
\hline & MSP & 85 & Sedang & 92 & Tinggi & 95 & Tinggi \\
\hline & MSRP & 89 & Sedang & 96 & Tinggi & 101 & Tinggi \\
\hline & SDH & 68 & Rendah & 83 & Sedang & 88 & Sedang \\
\hline & DRAR & 79 & Sedang & 92 & Tinggi & 95 & Tinggi \\
\hline & AS & 79 & Sedang & 101 & Tinggi & 102 & Tinggi \\
\hline & Mean= & 79,1 & Mean= & 92 & Mean= & 95,4 & \\
\hline Kelompok & Subjek & $\begin{array}{c}\text { Skor } \\
\text { Pretest }\end{array}$ & $\begin{array}{c}\text { Kategori } \\
\text { Skor }\end{array}$ & $\begin{array}{c}\text { Skor } \\
\text { Posttest }\end{array}$ & $\begin{array}{l}\text { Kategori } \\
\text { Skor }\end{array}$ & $\begin{array}{c}\text { Skor } \\
\text { Follow up }\end{array}$ & $\begin{array}{l}\text { Kategori } \\
\text { Skor }\end{array}$ \\
\hline \multirow[t]{11}{*}{ Kontrol } & BS & 88 & Sedang & 87 & Sedang & 87 & Sedang \\
\hline & RDS & 88 & Sedang & 86 & Sedang & 86 & Sedang \\
\hline & MYP & 87 & Sedang & 87 & Sedang & 86 & Sedang \\
\hline & RS & 69 & Rendah & 71 & Sedang & 71 & Rendah \\
\hline & $\mathrm{BaS}$ & 83 & Sedang & 82 & Sedang & 81 & Sedang \\
\hline & APM & 89 & Sedang & 88 & Sedang & 86 & Sedang \\
\hline & BRT & 79 & Sedang & 79 & Sedang & 77 & Sedang \\
\hline & WN & 66 & Rendah & 68 & Rendah & 68 & Rendah \\
\hline & RRM & 79 & Sedang & 79 & Sedang & 79 & Sedang \\
\hline & WNR & 67 & Rendah & 68 & Rendah & 69 & Rendah \\
\hline & Mean= & 79,5 & Mean= & 79,5 & Mean $=$ & 79 & \\
\hline
\end{tabular}

Selanjutnya adalah tabel hasil perbandingan pree test, post test, dan follow up kelompok kontrol dengan kelompok eksperimen. Kemudian dari data tersebut dilakukan uji hipotesis dengan teknik Mann Whithney dan Wilcoxon.

Tabel 4.

Tabel Hasil Uji Mann Whitney Pretest Kelompok Eksperimen dan Kelompok Kontrol

\begin{tabular}{cc}
\hline & Pree Test \\
\hline $\mathbf{Z}$ & $-0,266$ \\
\hline Sig (2-tailed) & 0,790 \\
\hline
\end{tabular}

Hasil pengukuran di atas didapat nilai $Z$ sebesar -0,266 dan nilai Asymp. Sig. (2-tailed) sebesar 0,790 $(p>0.05)$, yang menunjukkan bahwa tidak terdapat perbedaan antara skor pretest pada kelompok kotrol dan kelompok eksperimen. Dalam hal ini kelompok kontrol maupun kelompok eksperimen masih dalam keadaan yang sama.

Tabel 5.

Tabel Hasil Uji Mann Whitney Post Test dan Follow Up Kelompok Eksperimen dan Kelompok Kontrol

\begin{tabular}{ccc}
\hline & Post Test & Follow Up \\
\hline $\mathbf{Z}$ & $-3,485$ & -3.791 \\
\hline Sig (2-tailed) & 0.000 & .000 \\
\hline
\end{tabular}


Hasil pengukuran tersebut menunjukkan bahwa terdapat perbedaan yang signifikan antara kelompok yang tidak diberikan pelatihan kesadaran diri dibandingkan dengan kelompok yang diberikan pelatihan kesadaran diri. Sedangkan tabel berikut menunjukkan perbandingan skor pretest, post test, dan follow up pada kelompok eksperimen.

Tabel 6.

Hasil Uji Wilcoxon Kelompok Eksperimen

\begin{tabular}{ccc}
\hline Koefisien & Pre Test-Post Test & Post Test-Follow Up \\
\hline Z & $-2,809 \mathrm{a}$ & $-2,05 \mathrm{I}^{\mathrm{a}}$ \\
\hline Asymp.Sig. (2-tailed) & 0,005 & 0,012 \\
\hline
\end{tabular}

Hasil pengukuran dari kedua uji statistik wilcoxon tersebut dapat diartikan bahwa terdapat perubahan yang cukup signifikan setelah pemberian intervensi pelatihan kesadaran diri dalam meningkatkan kedisiplinan, dan memiliki pengaruh yang berkelanjutan setelah pemberian intervensi.

Tabel 7.

Hasil Uji Wilcoxon Kelompok Eksperimen

\begin{tabular}{ccc}
\hline Koefisien & Pre Test-Post Test & Post Test-Follow Up \\
\hline Z & $-0.087^{\mathrm{a}}$ & $-0.344^{\mathrm{a}}$ \\
\hline Asymp.Sig. (2-tailed) & 0.931 & 0.731 \\
\hline
\end{tabular}

Hasil pengukuran dari kedua uji statistik wilcoxon tersebut dapat diartikan bahwa tidak terdapat perubahan yang cukup signifikan setelah pemberian intervensi pelatihan kesadaran diri dalam meningkatkan kedisiplinan.

\section{Pembahasan}

Berdasarkan hasil uji hipotesis yang dilakukan dapat disimpulkan bahwa pelatihan kesadaran diri efektif dalam meningkatkan kedisiplinan siswa SMK. Dengan demikian hipotesis yang diasumsikan oleh peneliti dapat dinyatakan diterima. Hasil analisis data tersebut juga dapat diartikan bahwa pelatihan kesadaran diri dapat dijadikan salah satu model pelatihan untuk meningkatkan kedisiplinan siswa. Hasil uji hipotesis tersebut diperkuat dengan hasil wawancara dan observasi pada siswa setelah diberikannya pelatihan, dimana siswa sudah mulai mengatur jam tidurnya agar tidak terlambat sekolah, dan tidak tertidur di kelas. Sudah mampu mengurangi intensitas membolos, dan mengurangi keluar pada jam pelajaran (siswa lebih pada mengulas materi pelajaran, dan menekuni hobi di dalam kelas ketika jam kosong dari pada ke kantin atau pulang sebelum waktunya), sudah mampu menyiapkan atribut sekolah agar tidak tertinggal atau tidak memakai, dan berusaha tidak mengeluarkan baju seragam ketika di sekolah. Siswa berusaha langsung masuk ke kelas ketika bel masuk berbunyi, siswa juga berusaha mengerjakan tugas sekolah dengan sebaik mungkin (ketika mendapat tugas langsung dikerjakan pulang sekolah agar tidak lupa). Dan siswasudah tidak merokok di lingkungan sekolah karena takut ketahuan guru lalu dihukum.

Hal tersebut sesuai dengan pendapat Abdurohman (2004) yang menjelaskan bahwa perilaku disiplin seseorang berhubungan dengan kesadaran diri dalam diri orang tersebut, individu dinilai baik dalam belajar apabila mereka melaksanakan secara sadar dan terus-menerus hal-hal yang telah ditetapkan atau telah di programkan oleh sekolah. Kesadaran diri ini berfungsi memampukan individu dalam merencanakan perilaku,kemampuan yang diperkuat dengan adanya kesadaran diri akan memberikan individu tersebut kemampuan bertahan hidup yang lebih besar dalam lingkungan (Damasio, 1999).

Pada usia remaja sangat rentan terpengaruh terhadap pendapat orang lain, oleh karena itu keadaan sadar dan paham pada lingkungan sekitar akan membuat individu memiliki proses kognitif yang baik 
dalam diri, seperti ingatan, pemikiran, emosi, dan reaksi fisiologisnya. Jika remaja memiliki kesadaran diri yang baik, maka remaja tersebut dapat memilih mana yang termasuk perilaku positif dan perilaku negatif (Solso, 2008). Yang selanjutnya, remaja tersebut juga akan memiliki kesadaran akan dirinya dan kesadaran pada lingkungan sekitarnya, seperti kesadaran akan pikiran, perasaan, ingatan, dan intensitasnya (Skinner (dalam Feist \& Feist, 2013).

Pelatihan kesadaran diri pada penelitian ini menggunakan pendekatan pembelajaran melalui pengalaman (experiential learning). Experiential learning merupakan suatu pembelajaran tentang pengetahuan yang tercipta berdasarkan hasil perpaduan antara perubahan pengalaman(experience) dan pengetahuan. Pengalaman mempunyai peran utama dalam proses pembelajaran dalam experiential learning (Kolb, 1996). Tahapan proses belajar dalam pelatihan kesadaran diri ini yaitu berupa memahami diri, mengenali diri, pengakuan diri secara akurat, analisis diri (relaksasi) dan mengekspresikan diri.

Tahapan proses belajar pelatihan kesadaran diri terbagi menjadi tujuh sesi, yang bertujuan untuk meningkatkan kedisiplinan siswa. I) Sesi pertama pembukaan, yang berisi mengenai pemberian informasi rangkaian pelatihan dan kontrak belajar 2) Sesi kedua memahami diri, dengan mengidentifikasi peristiwa yang pernah terjadi dalam diri dengan memahami perbedaan perilaku positif dan negatif. 3) Sesi ketiga mengenali emosi, dengan mengamati setiap emosi yang dirasakan, sehingga berpikir dampak yang akan ditimbulkan sebelum bertindak. 4) Sesi keempat pengakuan diri secara akurat, dengan memahami kelebihan dan kekurangan yang dimiliki diri sehingga mampu memecahkan masalah sendiri atas perilaku tidak disiplin dan penanganannya. 5) Sesi kelima refleksi diri, dengan mempraktikkan refleksi diri saat berpikir akan melakukan suatu pelanggaran, melakukan suatu perilaku pelanggaran, dan saat berkomunikasi dengan orang lain terutama teman agar tidak terpengaruh untuk melakukan pelanggaran. 6) Sesi keenam kepercayaan diri, dengan memotivasi diri dengan berusaha berani tampil dengan keyakinan diri, dan berusaha menunjukkan perilaku yang baik dihadapan guru. 7) Sesi ketujuh Penutup, yang berisi kristalisasi dan evaluasi.

Setiap tahapan pada sesi dalam pelatihan kesadaran diri memiliki tujuan yang saling berkaitan, dan mengarah pada satu tujuan utama yaitu mampu memberikan kesadaran diri kepada peserta sehingga peserta mampu mengambil keputusan yang tepat yang berkaitan pada perilaku disiplin di sekolah. Suatu hal paling penting yang mampu dicapai ialah kemampuan pencapaian peningkatan kedisiplinan, sehingga individu tidak akan melanggar ketertiban sekolah dan tidak lupa dengan tanggung jawab sebagai seorang siswa di sekolah. Pelatihan kesadaran diri yang telah dilakukan terbukti meningkatkan kedisiplinan terhadap siswa-siswa SMK yang sering melanggar peraturan sekolah, hal tersebut didapatkan dari hasil evaluasi yang dituliskan oleh peserta.

Peningkatan kedisiplinan tersebut menjadikan subjek mendapatkan pemahaman dan pengalaman secara langsung. Bandura (1986) dalam teori social cognition menyatakan, bahwa perilaku baru diperoleh melalui dua bentuk pembelajaran, yaitu pembelajaran melalui observasi dan pembelajaran aktif. Proses pembelajaran observasional terdiri atas empat tahap yaitu attention, retentention, production dan motivation. Tahapan attention pada penelitian ini melibatkan dirrect modelling (fasilitaor dan co-fasilitator) dan symbolic modeling (video dan permainan). Pada tahap attention peserta mendapatkan pengetahuan dengan metode ceramah, menonton video, dan game. Selama penyampaian informasi pada pelatihan, terjadi tahapan retention, dimana partisipan menyimpan informasi mengenai informasi yang didapat dalam ingatannya dan menggunakannya saat dibutuhkan.Selanjutnya tahapan production, pada saat mengerjakan lembar kerja berkaitan dengan pengetahuan yang telah disampaikan oleh model. Kemudian tahapan terakhir yaitu, motivation dimana peserta memiliki dorongan untuk melakukan informasi yang telah diperoleh, fasilitator menyadarkan peserta mengenai manfaat informasi yang diberikan sehingga peserta memiliki keinginan menerapkan informasi dan pengalaman yang telah diperoleh pada kehidupan sehari-hari. Proses observasi dengan melakukan modeling video testimoni memberikan informasi yang menjadikan peserta harus berpikir terlebih dahulu sebelum bertindak dan tidak akan melanggar peraturan sekolah secara berkelanjutan. Pada saat pembelajaran aktif, setiap individu mendapatkan pelajaran atau pola baru dari perilaku yang komplek melalui pengalaman langsung,dengan memikirkan dan mengevaluasi konsekuensi dari tingkah laku mereka. Dengan melalui role play 
suatu kasus, peserta mampu memerankan sehingga peserta mampu merasakan apa yang telah diperankan dan peserta juga mendapatkan pengalaman langsung dalam melakukan strategi kesadaran diri yang positif. Selain itu, melakukan relaksasi merupakan pengalaman yang didapatkan peserta dimana peserta merasa bahagia karena merasakan ketenangan, hal ini yang menguatkan mereka untuk tetap menerapkan apa yang telah dipelajari.

Berdasarkan hasil follow up mengalami peningkatan skor, dan hanya satu peserta yang mengalami penurunan skor. Hal ini menunjukkan bahwa terjadi pembelajaran yang berkelanjutan meskipun tidak diberikan pelatihan secara terus menerus. Hal ini disebabkan oleh adanya proses transfer of learning yang telah di dapatkan kemudian dilakukan oleh para peserta pelatihan kesadaran diri. Suatu pelatihan pada akhirnya dapat dikatakan berhasil atau efektif bila transfer of learning ini dapat dilakukan oleh para peserta pelatihan dengan baik. Peningkatan tersebut diantaranya subjek menjalankan komitmen berupa tidak terlambat, tidak membolos, tidak merokok di area sekolah, mengerjakan tugas yang diberikan oleh guru, memakai atribut lengkap, dan mematuhi peraturan sekolah yang lainnya. Selain itu juga lebih banyak memanfaatkan waktu untuk kegiatan positif yakni mempelajari buku materi atau menekuni hobi ketika jam kosong di kelas untuk mengurangi perilaku membolos saat jam sekolah. Semua itu dilakukan para subjek dengan berusaha mengatasinya dengan meminimalisir kemungkinan-kemungkinan perilaku negatif yang akan dimunculkan, seperti tidur tidak larut malam, dan lebih mempersiapkan perlengakapan sekolah lainnya

Secara keseluruhan dapat dinyatakan bahwa pelatihan kesadaran diri mampu meningkatkan kedisiplinan. Grafik dari skala kedisiplinan menunjukkan angka yang relatif naik, dapat disimpulkan bahwa pelatihan kesadaran diri dapat dijadikan salah satu model dalam meningkatkan kedisiplinan menaati peraturan sekolah.

\section{Kesimpulan}

Berdasarkan hasil analisis dan pembahasan dapat disimpulkan bahwa pelatihan kesadaran diri efektif untuk meningkatkan kedisiplinan siswa. Hal ini dapat dilihat dari data skor kedisiplinan siswa pada kelompok yang diberikan pelatihan kesadaran diri memiliki tingkat kedisiplinan yang lebih tinggi dibandingkan dengan kelompok yang tidak diberikan pelatihan. Peningkatan skor yang signifikan pada rentang pretest-postest terjadi pada kelompok eksperimen. Sementara pada rentang postestfollowup terjadi juga peningkatakan pada skornya. Dampak pemberian pelatihan setelah I minggu yaitu adanya perbedaan perilaku disiplin pada kelompok eksperimen. Peningkatan perilaku disiplin yang dialami siswa disebakan karena adanya faktor kesadaran diri akan pentingnya perilaku disiplin di sekolah, mendapat dukungan dari lingkungan sekitar, dan siswa juga dapat mempraktekkan teknik yang diberikan saat pelatihan. Kemudian siswa yang mengalami penurunan perilaku disiplin disebabkan oleh kurangnya konsistensi dalam mempraktekkan teknik pelatihan dan juga karena ajakan siswa lain untuk melakukan perilaku yang kurang disiplin. Perilaku disiplin siswa yang menetap baik dikarenakan siswa memiliki kesadaran yang baik akan pentingnya perilaku disiplin dan juga karena mendapat dukungan yang positif dari lingkungannya.

Temuan tambahan dalam penelitian ini adalah dengan diberikannya pelatihan kesadaran diri membuat siswa lebih bisa terbuka dengan permasalahan yang dihadapi di sekolah, dan lebih mengetahui kelebihan dan kekurangan yang dimiliki. Metode sharing dan presentasi dapat membuat siswa lebih aktif dan komunikatif dalam mengemukakan pendapat. Selain itu juga ditemukan bahwa faktor yang mendukung meningkatkan perilaku disiplin antara lain adalah kesadaran diri yang mampu mendorong siswa untuk menerapkan perilaku disiplin dalam dirinya, managemen waktu, dan dukungan dari lingkungan. Sedangkan faktor yang cukup menghambat adalah kurangnya kesadaran diri yang lebih ke arah negatif dan adanya faktor lingkungan.

Implikasi penelitian ini untuk siswa, pihak sekolah dan peneliti selanjutnya. Pada penelitian ini siswa diharapankan mampu mempraktikan strategi kesadaran diri yang sudah diperoleh dalam pelatihan kesadaran diri, seperti mengenali diri (kelebihan dan kekurangan), mengidentifikasi pikiran, 
perasaan dan perilaku, mengenali emosi, mampu mengakui diri secara akurat, dan menampilkan kepercayaan diri. Pihak sekolah diharapkan mampu memberikan beberapa strategi atau teknik yang terdapat dalam program pelatihan kesadaran diri kepada siswa yang kurang mampu berperilaku disiplin untuk mematuhi peraturan di sekolah. Pada penelitian selanjutnya diharapkan wajib memperhatikan karakteristik subjek, sehingga mempersiapkan kendala-kendala yang akan dihadapi nantinya.

\section{REFERENSI}

Abdurahman. (2004). Psikologi Pendidikan Tanpa Kekerasan Yogyakarta Tiara Wacana.

Ahmadi, A. (2007). Psikologi Umum. Jakarta: Rineka Cipta.

Arvianola, D. A., Muslim, M., \& Hidayat, S. W. (2016). Teknik Self Monitoring Untuk Meningkatkan Disiplin Tata Tertib Peserta Didik Di Sekolah. Consilium. Jurnal Program Studi Bimbingan Dan KonselingFirst Published, 4(2), 60-65.

Bandura, A. (1986). Social foundations of thought and action. Englewood Cliffs. NJ: Prentice Hall.

Baumann, C. (2016). School Discipline, School Uniforms and Academic Performance. International Journal of Educational Management, 30(6), 1003-1029.

Creswell, J. W. (2010). Research Desaign: pendidikan Kualitatif, Pendidikan Kuantitatif, dan Mied. Yogyakarta. PT Pustaka Pelajar.

Damasio, A. (1999). The Feeling of What Hoppen: Baby, Emotion and the Making Conciousness. London. Heineman.

Feist, J., \& Feist, J. G. (20I3). Theories of Personality. (Terj. Handriatno). Jakarta: Salemba Humanika.

Flurentin, E. (20I2). Latihan Kesadaran Diri (Self Awarness) dan Kaitannya dengan Penumbuhan Karakter. Jurnal Inspirasi Pendidikan, I(I), 9-I8.

Hadi, S. (20I5). Statistika. Yogyakarta: Pustaka Pelajar.

Haryuni, S. (2013) Penerapan Bimbingan Konseling Pendidikan Dalam Membentuk Kedisiplinan Layanan Bimbingan Pengembangan Diri. Edukasia: Jurnal Penelitian Pendidikan Islam, 8(2), 389-4I6.

Hatami, F., Ghahremani, L., Kaveh, M. H., \& Keshavarn, S. (2016). The Effect of Self-Awareness Training with Painting on Self-Efficacy Among Orphaned Adolescents. Researrch Paper, 4(2), 89-96.

Jinot, B. L. (2018). The Causes of a Lck of Discipline Among Secondary School Learners in Mauritisius. Mediterranean Journal of Social Sciences, 9(I), 35-46.

Kolb, D. A. (1996). Experiential Learning: Experience as The Source of Learning and Development. New Jersey: Prentice Hall.

Muchtar. (20I5). Upaya Meningkatkan Disiplin Siswa Melalui Layanan Bimbingan Kelompok Di Kelas XI Otomotif SMK N I Belimbing. Jurnal Pendidikan Dasar, 3(I), |9-3I

Nursetya, S. B., \& Kriswanto, E. S. (2014). Upaya Meningkatkan KedisiplinanSiswa Kelas X Sma Negeri I Wates Dalam Mengikuti Pembelajaran Penjasorkes Melalui Reinforcement(Penguatan). Jurnal Pendidikan Jasmani Indonesia, 10(6), 8-12.

Rasheed, S. P. (2015). Self-Awareness as a Therapeutic Tool for Nurse/ client Relationship. International Jounal of Caring Sciences, 8(I), 2II-2I6. 
Simba, N. O., Agak, J. O., \& Kabuka, E. K. (2016). Impact of Discipline on Academic Performance of Pupils in Public Primary Schools in Muhoroni Sub-Country, Kenya. Journal of Education and Practice, 7(6), I64-173.

Solso, R. L. (2008). Psikologi Kognitif (terjemahan).Jakarta. Erlangga.

Soolgi, H., \& Sungjae, K. (2016). An Integrative Literature Review on Self-Awareness Education/Training Programs in The Nursing Area. Perspectives in Nursing Science, 13(2), 56-69.

Sutton, A. (2016). Measuring The Effects Self Awareness Construction of The Self-Awareness Outcomes Questionnaire. Europe's Journal of Psychology, I 2(4), 646-658

Tu'u, T. (2004). Peran Disiplin pada perilaku dan Prestasi Siswa. Jakarta: PT. Grasindo.

Willis, S. S. (20I4). Remaja dan Masalahnya. Bandung: Alfabeta.

Yusuf, S. (200I). Psikologi Perkembangan Anak dan Remaja. Bandung: Remaja Rosdakarya. 